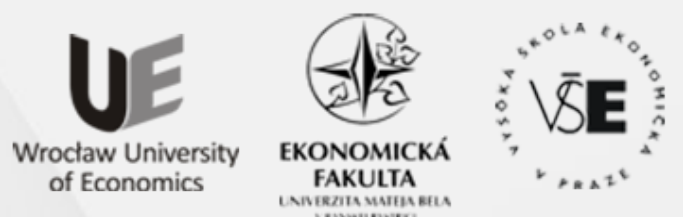

Conference Proceedings

Full TeXT PAPERS

edited by

Zofia Rusnak and Beata Zmyślona

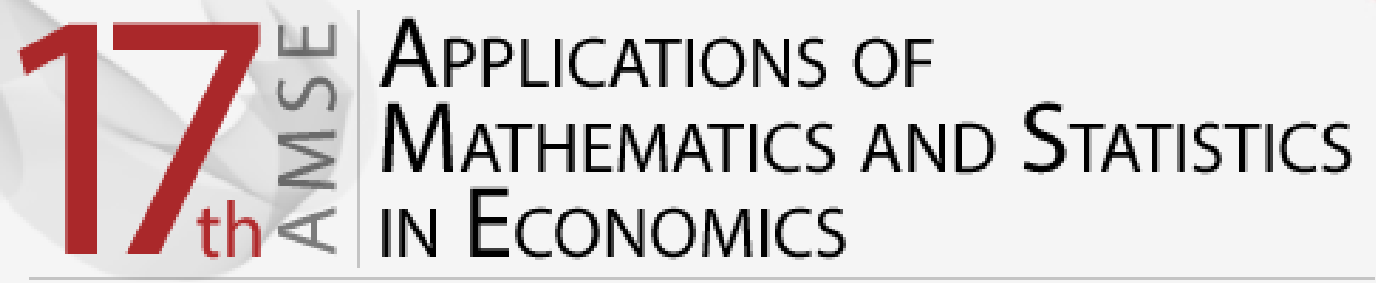

International Scientific Conference | Poland • 27-31 August 2014 
Scientific Committee

Richard Hindls, Stanislava Hronová, Rudolf Zimka, Walenty Ostasiewicz, Emília Zimková, Zofia Rusnak, Martin Bod'a

Organizing Committee

Beata Zmyślona, Cyprian Kozyra, Grzegorz Rogoziński, Kristýna Vltavská

\section{Reviewers}

Milan Bašta, Diana Bílková, Martin Bod'a, Joanna Dębicka, Tomáš Fiala, Jakub Fischer, Stanisław Heilpern, Karel Helman, Lenka Hudrlíková, Miroslav Hužvár, Nikola Kaspř́ková, Alena Kaščáková, Kamil Kladívko, Jindřich Klůfa, Pavol Král', Katarzyna Kuziak, Jana Langhamrová, Ivana Malá, Tomáš Marcinko, Luboš Marek, Miloš Maryška, Petr Mazouch, Zofia Mielecka-Kubień, Witold Miszczak, Petr Musil, Gabriela Nedelová, Walenty Ostasiewicz, Iva Pecáková, Viera Roháčová, Zofia Rusnak, Mária Stachová, Jana Špirková, Šárka Šustová, Jana Tepperová, Vladimír Úradníček, Kristýna Vltavská, Michal Vrabec, Dariusz Wawrzyniak, Henryk Zawadzki, Jaroslav Zbranek, Tomáš Zeithamer, Martin Zelený, Jan Zeman, Rudolf Zimka, Emília Zimková, Pavel Zimmermann, David Žižka

Layout

Martin Bod'a, Beata Zmyślona, Grzegorz Rogoziński

Front page design

Grzegorz Rogoziński

CD cover design

Beata Dębska

Articles published in the form submitted by the authors

All rights reserved. No part of this book may be reproduced in any form or in any means without the prior permission in writing of the Publisher

(C) Copyright by Wrocław University of Economics Wrocław 2014

ISBN 978-83-7695-421-9

Wydawnictwo Uniwersytetu Ekonomicznego we Wrocławiu

53-345 Wrocław, ul. Komandorska 118/120 www.ue.wroc.pl

Sprzedaż książek tel./fax 71 36-80-602

e-mail: econbook@ue.wroc.pl www.ksiegarnia.ue.wroc.pl 


\section{Contents}

Foreword

Diana Bílková: TL-Moments: Analogy of Classical L-Moments

Dagmar Blatná: Application of Robust Regression in the Analysis of Internet Access in European Countries

Martin Bod’a, Mária Kanderová: Rebalancing Issues in Tracking Error Variance Minimization

Martin Bod'a, Viera Roháčová: Application of Six Sigma Ideas to Timing Decisions at Financial Markets

Anton Dekrét, Rudolf Zimka: On the Price Hartwick's Task and Its Inverse in a Dynamic Model of an Economy with Exhaustible Resources

Joanna Dębicka, Agnieszka Marciniuk: Comparison of Reverse Annuity Contract and Reverse Mortgage on the Polish Market.

Petra Dotlačilová, Jitka Langhamrová: The Influence of Mortality Models for the Expected Future Life-time of Older People

Marek Ďurica, Lucia Švábová: Delta and Gamma for Chooser Options.

Vlastimil Farkašovský: New Concept of Pension Funds Performance Evaluation

Albert Gardon: The Normality of Weekly Relative Changes of the Freight Rate in Container Shipping.

Mária Grausová, Miroslav Hužvár, Jana Štrangfeldová: Healthcare Systems Efficiency in the Visegrád Group.

Stanisław Heilpern: Multiple Life Insurance - Pension Calculation

Alena Kaščáková, Gabriela Nedelová: Changes in Slovak Households' Economy

Igor Kollár, Pavol Král', Peter Laco: Methodology for Assessing Website Improvement in Corporate Environment.

Maciej Kostrzewski: Some Method of Detecting the Jump Clustering Phenomenon in Financial Time Series.

Cyprian Kozyra, Beata Zmyślona, Katarzyna Madziarska: Complementary Objective and Subjective Measures of Hospital Services Quality...

Pavol Král', Mária Stachová, Lukáš Sobíšek: Utilization of Repeatedly Measured Financial Ratios in Corporate Financial Distress Prediction in Slovakia

Ivana Malá: The Use of Finite Mixture Model for Describing Differences in Unemployment Duration

Lukáš Malec: Studying Economics and Tourism Industry Relations by Smooth Partial Least Squares Method Depending on Parameter. 
Tomáš Marcinko: Consequences of Assumption Violations Regarding Classical Location Tests.

Edyta Mazurek: The Income Tax Progression Depending on Social Insurance Contribution in Poland.

Petr Musil, Jana Kramulová, Jan Zeman: Regional Consumption Expenditures: An Important Starting Point for Regional Input-output Tables.

Katarzyna Ostasiewicz, Walenty Ostasiewicz: Good Life: From Political to Human Economy

Anna Sączewska-Piotrowska: Analysis of Poverty Transitions in Poland Using Multilevel Discrete-Time Event History Models

Martina Šimková, Petra Švarcová: Disadvantaged University Students in the Czech Republic.

Michal Široký: The Use of Short-term Business Statistics for Quarterly GDP Flash Estimates in the Czech Republic

Zdeněk Šulc, Hana Řezanková: Evaluation of Recent Similarity Measures for Categorical Data.

Lucia Švábová, Marek Ďurica: The Relationship Between the Finite Difference Method and Trinomial Trees

Kristýna Vltavská, Jaroslav Sixta: The Estimation of Final Consumption Expenditures

Lenka Vraná: Business Cycle Analysis: Tracking Turning Points

Janusz Wywiał: On Bayesian Testing in Auditing

Emília Zimková: Window Analysis of Supper-efficiency Change: Case of the Slovak Banking System ....

Beata Zmyślona: Statistical Modelling of the Impact of Diabetes on the Risk of Hospitalization 


\title{
GOOD LIFE: FROM POLITICAL TO HUMAN ECONOMY
}

\author{
KATARZYNA OSTASIEWICZ \\ Wrocław University of Economics, Faculty of Management, Information Systems and Finance, \\ Department of Statistics, Komandorska Street. 118/120, 53-345 Wrocław \\ email: katarzyna.ostasiewicz@ue.wroc.pl \\ WALENTY OSTASIEWICZ \\ Wrocław University of Economics, Faculty of Management, Information Systems and \\ Finance, Department of Statistics, Komandorska Street. 118/120, 53-345 Wrocław \\ email: walenty.ostasiewicz@ue.wroc.pl
}

\begin{abstract}
In this paper there is given a short account of shortages of a neoclassical economics, which came far away from Aristotelian political economy. Aristotle carefully distinguished two parts (sectors) of this economy: the art of wealth getting, which was considered by him as a part of the second art, the art of household management. The objective of it was a flourishing life or the Good Life. In the paper it is argued that economy as one of the social institutions, should serve the society instead to control it by means of market. All institutions are humanly devised for human purposes, and each of them can't be outside human control, as it is practice in the case of current market economy. The main aim of humankind is a development of desirable way of living and to sustain the quality of life also for future generations. The most significant new proposals are shortly reviewed in this paper. Moreover, it is argued that among many proposals the most suitable for quality of life studying is an ecological economics.
\end{abstract}

Key words: quality of life, neoclassical economics, ecological economics, sustainable development.

DOI: $10.15611 /$ amse.2014.17.23

\section{Introduction}

Modern terms "economics" and "economy" are derived from ancient Greek word "ekonomike", which was used to denote an art of household management. Households were natural human cooperative associations, which were embodied into wider social structure known as polis, city-states. Economics was therefore extended as far as to polis. This gave probably the reason for latter calling this knowledge as political economy. In Aristotelian sense economics was the practical knowledge that aids people to obtain and use the things that are necessary and useful for providing a descent life. The economy was considered as real actions of using the things required for pursuing the Good Life. A. Smith and all other the so called classical economists were influenced by ancient Greek thought. They combined economic issue with moral problems. They were worldly philosophers, as R. Heilbroner called them. Alfred Marshall was counted to this noble elite. It is worth to remember his definition of economics (see Hirschleifer (1985)): "Economics is a study of mankind in the ordinary business of life; it examines that part of individual and social action which is most closely connected with the attainment and with the use of the material requisites of wellbeing". J. Hirschleifer (1985) arrogantly described this definition as "terribly narrow, dull, bourgeois". Ironically enough, 
A. Marshall is known as one of the originators of neoclassical strand of economics, the strand which lost almost completely its real ground. Neoclassical economics according to R. Coase, became a theoretical system which floats in the air and which bears little relation to what happens in real world. The solutions offered by neoclassical economists are sterile, precise and elegant from mathematical point of view. It seems however it is much more useful to formulate and highlight the real problems, concern the lot of human being, even without giving solutions to them, than using exact mathematical methods to obtain exact solution of fictitious, abstract problems. The known anecdote illustrates this perfectly. Someone met an economist searching under the lamppost his key, although he lost it somewhere else, but he was searching his key where the light was. Despite the obvious evidence of the failure of the neoclassical economics, there are still numerous adherents to it. Some of them went as far as treating economics as the universal grammar of social science.

\section{Dismal science}

Till the beginning of XIX century the term political economy functioned as a counterpart of ancient Greek word "ekonomike". This term was for the first time used in 1615. Beginning in the XIX century it was changed for the term economics. Originally, Aristotelian economics was considered as a fundamentally moral science. The father of the so called classical economics, A. Smith, was influenced by an Aristotelian view on that science. Not only him, but all other classical economists combined philosophical and political issues with economical issues. Economists were considered as worldly philosophers, because of the breath and moral depth of economic enquiry. In his influential, highly readable book The worldly philosophers: the lives, times and ideas of the great economic thinkers, published in 1953 R. Heilbroner to the set of such thinkers includes A. Smith, K. Marx, J. M. Keynes, A. Marshall, and J. S. Mill. All of them were involved in important public policy issues with relevance to bettering the lives of people.

Unfortunately, this very noble, prime goal of economics aimed at supporting the good life, has been gradually downplayed and abandoned. Already in $1849 \mathrm{~T}$. Carlyle called the economics as a rueful or dismal science, because economics became a science in which all humans problems are reduced to "supply-demand analysis". He caricatured this science saying that it is enough to teach a parrot the terms supply and demand in order to get an economist. One hundred years after appeared the a book in which the defects of economics were thoroughly examined and explained. This was the the book "The great transformation, the political and economic origins of our time" published in 1944 by Karl Polany (1886-1964). K. Polany observed that the dynamic of modern society was governed by a double movement. The first one was an expansion of the market. He noticed that around 1914 almost every part of globe, all its inhabitants, physical persons, as well as fictitious bodies called corrporations, were compresed in it. The second movenent was countermovement against a "satanic mill", this was self-protection of society against self-regulating market. The whole economic activity is destinated to make a supply on the market, economy produce not with aim to meet people's needs, but for markets. Marketers will create demands. They are able to turn people into completely mindless consumers of any goods, even that, they do not want. K. Polany observed that fictitious commodities like land, labor and money makes human social life dependent upon the fluctuations of the market . Recently also people themselves are becoming commodities. A human billboard is a very mild example, this is a 


\section{$17 \backsim$ APPLICATIONS OF

person who is willing to place a temporary or permanent tattoo on their body for advertising purposes. Not only economy outputs, but many society's, highly essential constituents, are transformed into commodities. Not only the mentioned above places on human body being sold for ads, but even cadavers are transformed into commodities. Market economy gave rise to market society- the whole society is embedded in the mechanism of its own economy. This is depictured on Fig. 1.

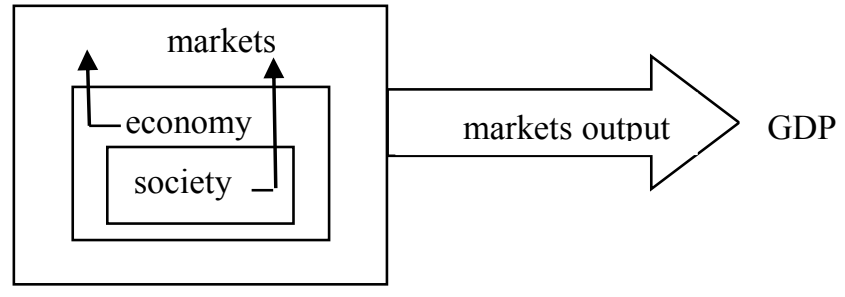

Source: own drawing.

Figure 1. Production for markets

\section{Mainstream economics}

Any science, particularly any social science, coexists with different schools of thought, or with a number of preferred approaches. As far as economics concerns, there were, from very early beginning of its development, different points of view on it, and only some of them reached the level to be named schools of thought. Among all having this privilege, the school of neoclassical thought conquered all others. For that reason it has been a mainstream economics. It has been never defined. It is impossible to indentify it precisely. Description of it which seems to be the closet to the reality is given by David Deuquech (2007): Mainstream economics is considered a form of knowledge, supported by the prestige of the universities in which it is thought and by the journals in which it is published. D. Colander (2000) gives a practical criterion to identify it: these are ideas that the elite in the profession find acceptable. He has highlighted also the essential attributes of this stream, distinguishing the following six the most important of them:

1. Allocation of resources at a given moment in time

2. Accepting utilitarianism as a sole ethical foundation

3. Focusing on marginal tradeoffs

4. Assumption of far-sighted rationality

5. Methodological individualism

6. Structuring collective behavior around a general equilibrium.

Neoclassical economics is meant to be about the policy design, to be a guide for decision makers. In the case of individual decision makers economics offers the tool called CostBenefit Analysis. The abbreviation CBA within the circles of mainstream economists needs not to be decipher.

In the case of collective behavior, this sort of economics has a magic tool known as invisible hand, which carry on the whole system into equilibrium state. The notion of equilibrium gained the status magic charm. There are distinguished two kinds of equilibrium: partial and general. The second of them cemented the whole so called welfare economics. 


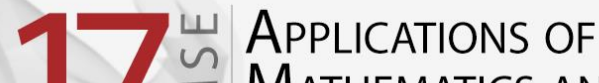

\section{Thinking with models}

According to J. M. Keynes economics is the science of thinking in terms of models. Suppose that economy consists of two sectors. One of them is formed by owners of natural resources, which are used as an input for production. The second sector uses natural resources together with human made capital to produce goods. Graphical presentation of such an economy is following

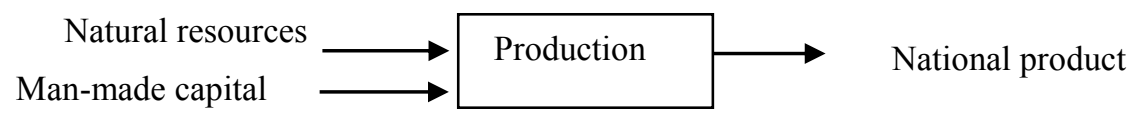

The prevalent assumption of neo-classical economics is that the sole source of well-being is consumption. It is rather natural to assume that natural resources are limited. In the light of these two assumption the following question is rather obvious: is the economy with exhaustible resources able to provide non decreasing consumption now and for all future generations?

Economists have proved that if owners of resources are rational and the society reinvest the rents from nonrenewable natural resources in other forms of capital, then the society can sustain a constant level of consumption that can go on forever.

This result is proved by using advanced mathematical methods, normally not included in curricula for economists education.

Without going into details, below there are specified explicitly, formally, all assumptions underlying this highly optimistic statement (see Asheim, Buchholz and Withagen (2003)).

1. Consumption is a continuous function $c: R_{+} \rightarrow R_{+}$, so that for any $t \epsilon[0, \infty)$ holds

$$
\lim _{\tau \rightarrow t} c(\tau)=c(t)
$$

2. Extraction of natural resource is a continuous function $r: R_{+} \rightarrow R_{+}$

3. Stock of man-made capital is a continuous ad differentiable function $c: R_{+} \rightarrow R_{+}$

$$
\lim _{\tau \rightarrow t} k(t)=k(t), \quad \lim _{\tau \rightarrow 0} \frac{k(t+\tau)-k(t)}{\tau}
$$

4. Remaining stock of exhaustible resource is a function defined as follows

$$
S(t)=S_{0}-\int_{0}^{t} r(\tau) d \tau
$$

where $S_{0}$ is the initial level of natural resource capital.

5. Natural resource capital is exhausted in infinite time and there holds

6. Production is defined by a function $F: R_{+} \times R_{+} \rightarrow R_{+}$

$$
\lim _{T \rightarrow \infty} \int_{0}^{T} r(\tau) d \tau \leq S_{0}
$$

which for any input $(k, r) \equiv(k(t), r(t)) \epsilon R_{+} \times R_{+}$assigns an output $F(k(t), r(t)) \epsilon R_{+}$and for any $\mathrm{t}>0$ there are fulfilled the following conditions

$$
\begin{gathered}
F(0, r(t))=F(k(t), 0)=0, \quad \frac{\partial F(k, r)}{\partial k}>0, \frac{\partial F(k, r)}{\partial r}>0, \frac{\partial^{2} F(k, r)}{\partial k \partial r}<0 \\
\quad \inf \left\{\frac{\partial F(k, r)}{\partial r} \frac{r}{F(k, r)} \mid(k, r) \epsilon R_{+} \times R_{+}\right\}>0
\end{gathered}
$$

7. In any period $t \epsilon[0, \infty)$ the Hotelling rule is fulfilled 


\section{APPLICATIONS OF

$$
\frac{d}{d t}\left(\frac{\partial F(k(t), r(t))}{\partial r}\right)=\frac{\partial F(k(t), r(t))}{\partial k} \cdot \frac{\partial F(k(t), r(t))}{\partial r}
$$

In any period $t \in[0, \infty)$ the Hartwick rule is fulfilled

$$
\frac{\partial F(k(t), r(t))}{\partial r} r(t)=F(k(t), r(t))-c(t)
$$

8. The development of the economy is described by two differential equations:

$$
\begin{aligned}
& \frac{d k(t)}{d t}=F(k(t), r(t))-c(t), t>0 \\
& \frac{d S(t)}{d t}=-r(t), t>0
\end{aligned}
$$

The system of three functions $P=(c(t), k(t), r(t))$ considered as the mapping (multifunction): $P: R_{+} \rightarrow R_{+} \times R_{+} \times R_{+}$is called a time path (of consumption, investment, and extraction) starting from the initial stock $S_{0}$, and initial capital $K_{0}=k(0)$. All possible path are denoted by $\Phi\left(K_{0}, S_{0}\right)$. If there exists such a path $c(t)$ that $c(t)=c$ for all $t \epsilon[0, \infty)$, then a path $(c(t), k(t), r(t)) \in \Phi\left(K_{0}, S_{0}\right)$ is called egalitarian path. A path $(c(t), k(t), r(t)) \in \Phi\left(K_{0}, S_{0}\right)$ is said to be a maximin path or Rawlsian path if the inequality $\inf \{c(t) \mid t \epsilon[0, \infty)\} \geq \inf \left\{c^{\prime}(t) \mid t \in[0, \infty)\right\}$

is satisfied for all paths $\left(c^{\prime}(t), k^{\prime}(t), r^{\prime}(t)\right) \in \Phi\left(K_{0}, S_{0}\right)$.

If a path $(c(t), k(t), r(t)) \in \Phi\left(K_{0}, S_{0}\right)$ satisfies the Hartwick rule, then it is called Hartwick path.

The necessary and sufficient conditions for the existence of different kinds of paths are very complicated. For the aim of this paper it will be sufficient to consider very special variant of production function. Suppose that production is described by the Cobb-Douglas function

$$
Q=F(k, r)=[k(t)]^{\alpha} \cdot[r(t)]^{\beta}, \quad \alpha+\beta \leq 1
$$

If $\alpha>\beta$, then maximum egalitarian consumption is given by the formula

The extraction level is defined by the equation

$$
c_{0}=(1-\beta)\left[(\alpha-\beta) \cdot S_{0}\right]^{\frac{\beta}{1-\beta}} K_{0}^{\frac{\alpha-\beta}{1-\beta}}
$$

$$
r(t)=\left(\frac{c_{0}}{1-\beta}\right)^{1 / \beta} \cdot[k(t)]^{-\alpha / \beta}
$$

Using (1) we can determine the stock of natural resource in any instant of time, and from (4), the state of capital in any instant of time

The marginal productivity of resource in the case of Cobb-Douglas function is

$$
\frac{\partial F(k(t), r(t))}{\partial r}=\beta[k(t)]^{\alpha} \cdot[r(t)]^{\beta}=\beta k^{\alpha} r^{\beta-1}
$$

The rents from the resource are calculated as rents $=$ productivity $\cdot$ extraction

So that one has

$$
\frac{\partial F(k(t), r(t))}{\partial r} r(t)=\beta k^{\alpha} r^{\beta-1} \cdot r=\beta k^{\alpha} r^{\beta}
$$

Hartwick rule requires that this amount of production must be reinvested:

$$
\frac{d k(t)}{d t}=\beta \cdot[k(t)]^{\alpha} \cdot[r(t)]^{\beta}
$$

And the rest of production can be consume, this rest is equal to the quantity:

$$
(1-\beta)[k(t)]^{\alpha} \cdot[r(t)]^{\beta} \text {. }
$$

Dynamic of that economy is depictured on Fig.2 


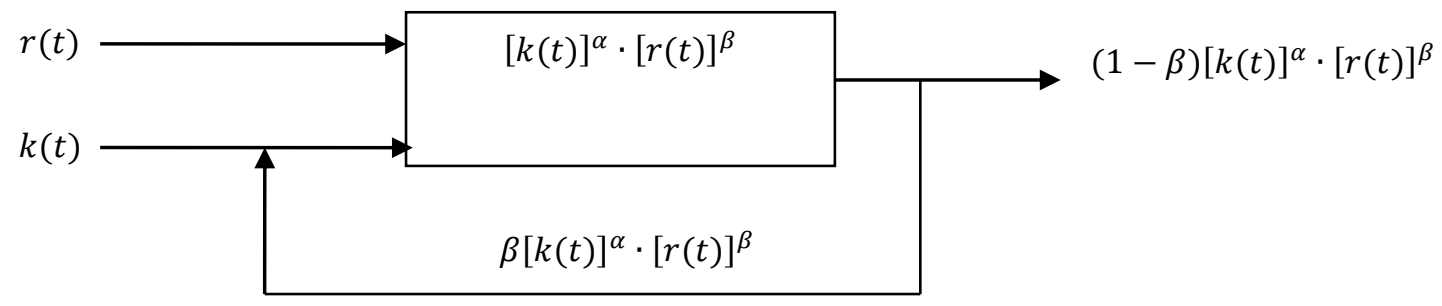

Figure 2. Dynamic of the economy

Source: own drawing.

Suppose that $S_{0}=1, K_{0}=1$, and $\alpha=0.7, \beta=0.3$, then the consumtion enjoyed by all generations, at any instance of time, is following:

$$
c_{0}=(1-0.3)[(0.7-0.3) \cdot 1]^{\frac{0.3}{1-0.3}} 1^{\frac{0.7-0.3}{1-0.3}}=0.472664
$$

Processes of resource extraction is

$$
r(t)=\frac{5.931}{(12.931+3 \mathrm{t})^{1.207}}
$$

Stocks of man-made capital, and of a ntural resource are following:

$$
k(t)=0.266(12.931+3 t)^{0.517}, \quad s(t)=1-5.931\left(0.948-\frac{1.611}{(12.931+3 t)^{0.206}}\right)
$$

This highly "optimistic" result is mainly due to Hartwick. It became very famous and attractive because it gave an essential extension to the basic result of the theory of growth proposed by Solow. The Hartwick result means that exhaustible resources can be substituted by human made capital in such a way that the depleting natural resources will cause no harm for future generations, as a constant consumption can be sustain forever. Commenting on this result, Solow (1974) went as far as to declare that "the world can, in effect, get along without natural resouces". It has come out that Hartwick's rule plays an important rule in wider class of models dealing with natural resources. Therefore a question has arisen to find out the real meaning of Hartwick's rule. This question has been studied for example in the works of

Dasgupta and Heal (1974 ), and Dasgupta and Mitra (1984)

In order to shed more light on the essence of these assumptions there are given below some verbal comments to the used mathematical formulations.

1. Natural capital consits of natural resources renewable and non-renewable, such as water soil, fosil fels, forest etc. One can wonder if it reasonable to assume that all of them are treated as one, homogenous composite good measured by a positive real number.

2. Consumption has been defined for any instant of time $t$, till infinity. This means nothing else as to consider one infinately lived representative individuum

3. The same is assumed for an agent owning resource. For deriving his rule Hotelling assumed the following: "Since it is a matter of indifference to the owner of a mine whether he reinvests for a unit of his product a price $p_{0}$ now or a price $p_{0} e^{\gamma t}$ after time $\mathrm{t}$, it is not unreasonable to expect that the price $p$ will be a function of the time of the form $p=$ $p_{0} e^{\gamma t}$." (Hotelling(1931)). So that this infinitely lived owner decides now about the price after 100 years or more.

4. The above assumpition is equivalent to the assumption that at any instant of time future generations will be continuously wealthier and wealthier

5. For all "real" individuals (which are living in very limited time not infinitely), the Nature is much more than an input for good production. Hartwick rule depends specifically on particular production function assuming substitution of depleted natural resources by 
artificial capital. So that it is fully acceptable that the last fish used for the production can be substituted by a fish rod.

6. Hartwick's investment rule, defined as a prescriptive rule, is hardly to be practically applicable. First, it requires massive government, or a central planner, intervention in capital market, second, it is not clear how much it should be invested by the private sector versus the public ivestments. One question is also whether this rule is truly prescriptive. Critic is based on the observation that a commitment to invest resource rents now cannot commit future generations to do the same.

7. The expression "intergenerational equity" is quite clear: the present generation is as well off as the any future generation. In the model presented above generations are identified with instants of time.

8. Theorem about the maximum sustainable consumption depends also on the initial level of natural resources. If that level is big enough, then all generations can be able to enjoy the same level of consumption. To comment on this assumption it is worthy to quote the known Daly's sayng: if the wishes were horses, then beggers will ride.

\section{Voices for change}

Polany's book remained unfortunately unnoticed for many years. Yet around 1960s emerged a wider rebellion against the market hegemony. Bertram M. Gross was probably one among the first who voiced for change. He argued that economists using their economic analysis excludes all important aspects of social life. The tendency of using omnipotent monetary rod for measuring social phenomena he described as a new Philistinism. Initiated world wide movement of social indicators was hindered by rising Reaganomics. The other reason for the hibernation of that movement was that it rised outside of the terrain of eonomics reign. The very firestorm was set off in 1967 by Ezra Mishan a well-respcted economists by his book "The costs of economic growth". His view was therefore taken seriously in the circle of mainstream economics. Mishan's book "was an urgent plea to the thoughtful people to ponder the effects on the welfare of ordinary people of a gathering erruption of science and technology in pressure sufficient to splinter the framewoek of our institutions and to erode the moral foundations on which they have been rised" (Heines (2013)).

\section{Towards human economy}

Economic system functions in interaction with other systems, and as all the other social institutions is embeded in environmental system. Economy includes, as its part the market mechanisms, which must be subordinated to economy, not vice versa. This view is with an accordance of a variant of new economics known as the ecological economics, founded by H. Daly (see Gowdy, Ericson (2005)). This alternative to neoclassical welfare economics provides a good foundation for policy recommendation. Vernon L. Smith when he received the Bank of Sweden Prize in Economics in Memory of Alfred Nobel in 2002 , delivered a lecture in which he thoroughly explained the notion of ecological rationality. This kind of rationality uses the reason to examine the behavior of individuals based on their experience and folk knowledge to apply constructivist tools to the decision they make, but also to understand the emergent order in human cultures that are created from human interactions but not by deliberate human design. Ecological rationality is based on the ability to exploit the information in natural environment. T. Lawson (2007) defends also the view that the social realm, embedded in natural environment, is emergent from human interaction, but it does not reduce to human practices. This kind of social system underlie the another approach to reshaping neoclassical economics, called green economics. 


\section{Towards the science of human being}

At the beginning of 2008 there was created on French government's initiative the Commission on the measurement of economic performance and social progress. One of the main reasons for its creating was the raised since a long time the problem of inadequacy of current measurement of economic performance by widely criticized GDP index. The Commission, chaired by Joseph E. Stiglitz, published in 2009 the report, which contains two main messages (see Stiglitz, Sen, Fitousi (2009)). The first main message is "that the time has come to adopt our system of the measurement of economic activity to better reflect the structural changes which have characterized the evolution of modern economics". The second "key message, and unifying the theme of the report, is that the time is ripe for our measurement system to shift emphasis from measuring economic production to measuring people's well-being". These two messages are the departure point for this part of the paper. The first essential remark which is stressed here is that Stiglitz's report has been written from the purely economists perspective. Economy is in the center of the whole inqiury, moreover it is considered as an autonomous system besides two others: social and environmental systems. Instead of the three pillar approach, the so called Russian dolls model should be applied, with the economy as a most inferior doll. Economy is one of the social institutions, and as any others, is designated to perform well determined tasks, the aim of all of them is a betterment of human being. The economics, as a body of knowledge about this institution should support the achievement of this goal. This means simply that economics should be considered as a science of human being. Usually the term of well-being is used. For many people much more appropriete term is a term of ill-being, so that the term human being seems to be more suitable then the human well-being. The right to judge on the human beings belongs only to the society. Society is however in its turn very complex system ambracing verious organizations and institutions. All instituions are designed with the scope of perfoming particular taksks. The quality of human living depends on how these tasks are performed. One needs therefore tools for the performance measurement. Economy, as one of the institutions designated by the society should be not the master of people's lives, but the servant of human flourishing . Human beings are authorized to judge the quality of servants (institutions). Apart from this institutional performance, one needs also to measure environmental performance. Graphical presentation of the general scheme for quality of human life measurement is presented on the Fig. 3.

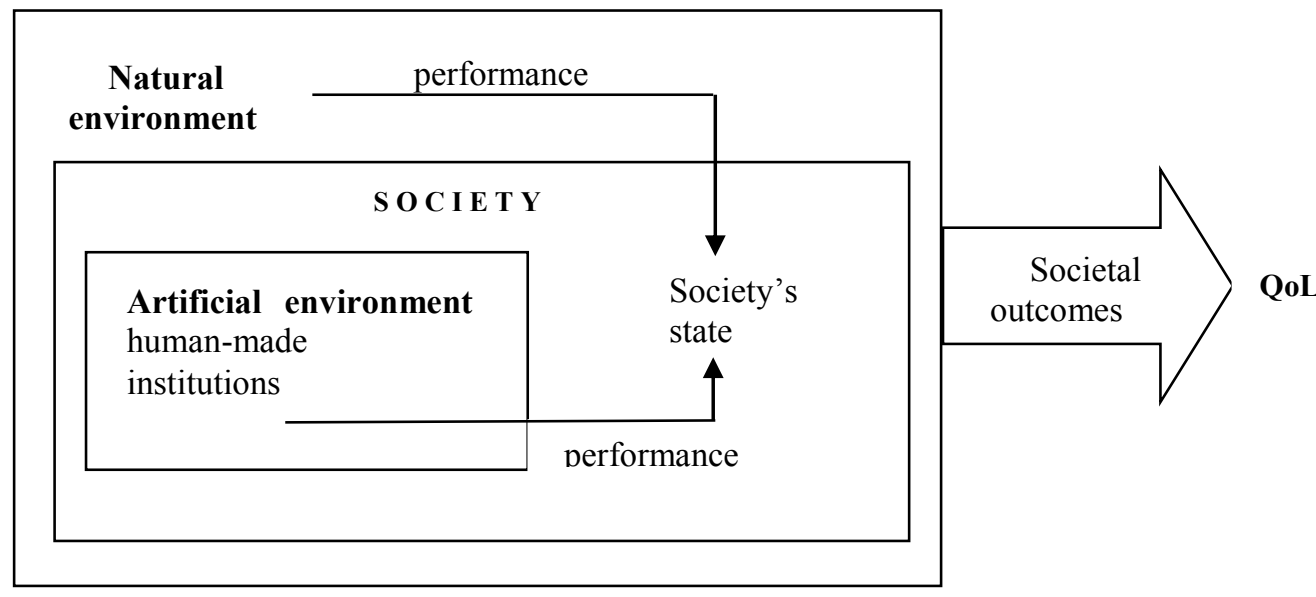

Figure 3. Scheme of well-being measurement

Source: own construction. 
Both, natural environment, or biophysical system and social system are not simply a collection of elements, they are self regulating very complex systems. They have therefore their inherent characteristics, apart of their performance. These performances, needed and desired by people, depend on the wellness of that systems, their capacity to perform expected tasks. The basic feature characterising biophysical system is its resilience. For social system such an syntetical gauge of its state can be cohesion. Social cohesion is strictly connected to inequality. This issue was till recently neglected by social researchers, and especially by economists focusing on growth and wealth considered in total. As key cross-cutting issueu that was even neglected in the Millenium Development Goals. It is worth to quote here E. Neumayer's observation: "Many academics and public intellectuals have recently voiced grave concer about increasing inequality and its detrimental social effects, not leas by slowly destroying the social fabric and public spirit on which the private and public welfare of all societies are builed" (see Neumayer (2010)). The increasing endemic of inequality concerns not only income, but also health care, education, personal security, personal activity and influence on public decision making, generally in human development. Equality, or more fundamentally, equity, is integral to human development. Not utilitarianism, but ethical individualism, as promoted by A. Sen, should form the moral base for the new economics. The efforts to create such an economics are recently undertaken by a number of institutions, chiefly of the NGO types, or even by individual persons. In any case endeavours are directed towards creating a science having perspective to improve the human lot. Already Aristotle wrote that just talking about virtue not make a man virtuous. To become virtuous he has to act. The same one can say about more modest concept of well-being, one needs to act. Actions needs the guide and the tools. Among the all possible tools, a system of social indicators plays a central role. During the last fifty years there were proposed a number of concepts of social indicators. Almost all developed indicators are influenced by utilitarian theory. They are strongly directed towards maximization of total benefits. An alternative to utilitarian stand point is Rawlsian appeal for protecting a minimum level of dignity. Typical utilitarian measure is the GDP, the machine that can only add. This measure has been "corrected" by subtracting undesirable outputs such as pollution, depletion, loss of enjoyment by people etc. The resulting index is Genuine Progress Index (see Cobb (2000)). Natural and human beings are not antagonistic, they always were partners in evolution. M. Bookchin in many of his writing tried to create a unified theory of natural and social worlds. They both should be considered as a cooperating systems, and therefore should be evalualted from the systemic perspective. Social realm has an emergent structure, the properties of which cannot be reduced to the phenomena from which a system is emerged. The system as a whole can suffer illness, and its components (people) can also fill unwell. Social ills, environmental burden, harmony, or cohesion, that are typical collective, systemic, characteristics. This means that one thing is a measurement of wellness of natural or social system, and the other thing is a measurement of wellnes of pepople or hausholds. The system of social accounting proposed in this paper comprises the three basic components as its sub-systems:

- State and performance of natural system

- State and performance of social system( economic, health care, education)

- People's daily-life experience.

The frist two sub-systems, mentioned above, offer opportunities for living a desired lives. In principle, performance measurement means the measurement of these opportunities. Opportunities, or conditions form only the base for good living. They would be useless if 
people will be not able to use them. High culture is but a set of artefacts without persons who can appreciate and interpret it Quality of living does not depend only on the conditions. As R. Lane rightly observed, the quality of life depends also on quality of person. In his capability theory A. Sen points out that freedom is worhless without capacities and willingness to use of it (see Offer (1996)). R. Lane give a list of nine opportunities i.e. quality of conditions for quality of living). These conditions are following: adequate material support, physical safety and security, available friends and social support secure, opportunities for the expressing and receipt of love, opportunities for challenging work, the kinds and amounts of leisure, available set of moral values that can giving meaning to life, opportunities for selfdevelopment, with the assistance of such help as may be needed, objective justice(see Offer (1996)). The open problem remains how assure the corresponding properties of quality of person in order persons are to be capable to exploit the opportunities. The other, often discussed problem is the question of self-assessment versus external assessment. The view presented in this paper is as follows. The states and performances are to be assessed externally. These assessments should be confronted with people's sense.

\section{Acknowledgement}

We are very obliged to Professor Rudolf Zimka for his help, valuable comments and friendly suggestions, although, ideologically we are at variance with him

\section{References}

1. ALKIRE, S. 2010. Human development: definitions, critiques, and related concepts, Research Paper 2010/01, UNDP, 2010

2. ASHEIM, G.B., BUCHHOLZ, W., WITHAGEN, C. 2003. The Hartwick Rule: Myth and Facts. Environmental and Resource Economics, Vol. 25, 129-150.

3. Cobb, C. W., Measurement tools and quality of life, Redefining Progress, June, 2000.

4. COLANDER D.,C. 2000. The Death of Neoclasical Economics, Journal of the History of Economic Thought, 22, 127-142 .

5. DASGUPTA, P., HEAL, G. 1974. The Optimal Depletion of Exhaustible Resources. The Review of Economic Studies, Vol. 41, 3-28.

6. DASGUPTA, P., MITRA, T. 1983. Intergenerational Equity and Efficient Allocation of Exhaustible Resources, Intl. Econ Rev. 24, 133-153.

7. DEQUECH D., 2007. Neoclassical, mainstream, orthodox, and heterodox economics, Journal of Post Keynesian Economics, 30(2), 279-302

8. GOWDY, J., ERICSON J. D. 2005. The approach of ecological economics, Cambridge Journal of Economics, 29, 207-222

9. HAINES Ch. 2013. Reclaiming Progress by Limiting Economic Growth, Journal of Sustainability Education, 5, 1-11

10. HIRSHLEIFER J., 1985. The expanding domain of economy, The Amer. Economic Review, 76, 53-68

11. HOTELLING H. 1931. The economics of exhaustible resources, The Journal of Political Economy, 2, 137-175

12. LAWSON, T. 2007. An orientation for a green economics?, Int. J. Green Economics, Vol. 1, 250-267 
13. NEUMAYER, E. 2010. Sustainability and inequality in human development and, Research Paper 2011/04, UNDP

14. OFFER, A. (ed.) 1996. In pursuit of the quality of life, Oxford University Press

15. SOLOW, R. M. 1974. Intergenerational Equity and Exhaustible Resources. The Review of Economic Studies, Vol. 41, 29-45.

16. STIGLITZ E., SEN A., FITOUSI J-P. 2009. Report by the Commission on the Measurement of Economic Performance and Social Progress. Technical Report, Commission on the Measurement of Economic Performance and Social Progress. 